\title{
HIV in Europe and Central Asia: progress in 2018 towards meeting the UNAIDS 90-90-90 targets
}

Alison E Brown ${ }^{1,2}$, Rosalie Hayes ${ }^{3}$, Teymur Noori4, Yusef Azad³, Andrew J. Amato-Gauci ${ }^{4}$, Anastasia Pharris ${ }^{4}$, Valerie C. Delpech ${ }^{1,5}$, the ECDC Dublin Declaration Monitoring Network ${ }^{6}$

1. Public Health England, London, United Kingdom

2. Independent Consultant, London, United Kingdom

3. National AIDS Trust, London, United Kingdom

4. European Centre for Disease Prevention and Control, Stockholm, Sweden

5. Independent Consultant, Watipa, London, United Kingdom

6. The ECDC Dublin Declaration Monitoring group are listed at the end of the article

Correspondence: Alison E Brown (alison.brown@phe.gov.uk)

Citation style for this article:

Brown Alison E, Hayes Rosalie, Noori Teymur, Azad Yusef, Amato-Gauci Andrew J., Pharris Anastasia, Delpech Valerie C., the ECDC Dublin Declaration Monitoring Network. HIV in Europe and Central Asia: progress in 2018 towards meeting the UNNAIDS 90-90-90 targets. Euro Surveill. 2018;23(48):pii=1800622. https://doi. org/10.2807/1560-7917.ES.2018.23.48.1800622

Article submitted on 15 Nov 2018 / accepted on 29 Nov 2018 / published on 29 Nov 2018

In 2018, 52 of 55 European and Central Asian countries reported data against the UNAIDS 90-90-90 targets. Overall, $80 \%$ of people living with HIV (PLHIV) were diagnosed, of whom $64 \%$ received treatment and $86 \%$ treated were virally suppressed. Subregional outcomes varied: West $(87 \%-91 \%-93 \%)$, Centre $(83 \%-$ $73 \%-75 \%)$ and East (76\%-46\%-78\%). Overall, $43 \%$ of all PLHIV were virally suppressed; intensive efforts are needed to meet the 2020 target of $73 \%$.

In 2014, the Joint United National Programme on HIV/ AIDS (UNAIDS) established the global 90-90-90 targets. The aim was for $90 \%$ of all people living with HIV (PLHIV) to be diagnosed, 90\% of those diagnosed to receive antiretroviral treatment (ART) and 90\% of those receiving treatment to achieve viral suppression, by 2020 [1]. Here, we describe progress towards the UNAIDS 90-90-90 targets across Europe and Central Asia and discuss whether current performance is sufficient to eliminate HIV transmission.

\section{The Dublin Declaration on Partnership to Fight HIV/AIDS}

Between January and March 2018, the European Centre for Disease Prevention and Control (ECDC) disseminated an online survey to the 55 countries of Europe and Central Asia that comprise the World Health Organization (WHO) European Region, to monitor the implementation of the Dublin Declaration on Partnership to Fight HIV/AIDS [2]. Countries provided estimates of the number and proportion of people within a defined four-stage continuum of care for the most recent year available (Box) $[3,4]$.

Countries also specified the year to which the estimates related, data sources and collection methods and uncertainty bounds for each continuum stage.
Where necessary, data were supplemented using Global AIDS Monitoring (GAM) indicators collected by UNAIDS. Data were validated by countries between May and November 2018 and updated accordingly.

\section{Definitions and analyses}

The global 90-90-90 targets are assessed as percentages of each previous stage of the continuum. The 'substantive target' is defined as the percentage of all PLHIV who are virally suppressed, making $73 \%$ the target (Figure 1). The global targets include countries reporting at least two consecutive stages but the substantive target only includes countries reporting all four stages of the continuum. Data were presented by WHO European subregion (West, Centre and East) which categorises countries in Europe and Central Asia in to three geographic areas by HIV epidemic type [5]. At the (sub)regional level, analyses were undertaken after summing each continuum stage across countries [3]. Data were compared with that previously submitted through the Dublin Declaration survey $[3,6,7]$.

\section{Key findings}

In 2018, 52 of 55 countries completed the survey with 34 providing data across all four continuum stages (compared with 29 in 2016) and 42 providing at least two consecutive stages (compared with 41 in 2016). In 2018, progress towards the global 90-90-90 targets in Europe and Central Asia stands at $80 \%-64 \%-86 \%$. In the West subregion, $87 \%-91 \%-93 \%$ was achieved with equivalent figures at $83 \%-73 \%-75 \%$ and $76 \%-$ $46 \%-78 \%$ in the Centre and East, respectively. In countries in the European Union/European Economic Area (EU/EEA), which includes countries from each of the subregions, the progress stands at $86 \%-91 \%-92 \%$. The number and proportion in each continuum stage are presented in the Table. 


\section{BoX}

Four-stage continuum of HIV care, global UNAIDS 9090-90 target and substantive target

Stage 1: Estimated number of people living with HIV

Stage 2: Number/percentage of stage 1 diagnosed

Stage 3: Number/percentage of stage 2 receiving ART

Stage 4: Number/percentage of stage 3 with viral load $<200$ copies/mL (considered as virally suppressed)

- Global UNAIDS 90-90-90 target:

First 90: Number/percentage of all PLHIV who are diagnosed

Second 90: Number/percentage of those diagnosed who are treated

Third 90: Number/percentage of those treated who are virally suppressed

- Substantive target:

Number/percentage of all PLHIV who are virally suppressed.

ART: antiretroviral therapy; PLHIV: people living with HIV.

Source: Gourlay et al [4] performance can be compared between 2016 and 2018 (Figure 2); outcomes improved from $82 \%-85 \%-89 \%$ to $85 \%-89 \%-91 \%$ for the global targets, respectively. Overall $69 \%$ of all PLHIV were virally suppressed in 2018 compared with $62 \%$ in 2016 . Improvements in the substantive targets were observed in all subregions (the $1 \%$ decline in percentage diagnosed in the Centre subregion is likely due to a revision of the estimate of undiagnosed PLHIV). Viral suppression among all PLHIV was $74 \%$ (West), 45\% (Centre) and 25\% (East) in 2018 , compared with $67 \%, 34 \%$ and $16 \%$ in 2016 , respectively.

The number of people with transmissible levels of virus can be calculated by adding the number of PLHIV estimated to be undiagnosed, diagnosed but untreated and treated but not virally suppressed (for countries providing all four stages. An estimated $57 \%$ (1.2 million/2.1 million) PLHIV are presumed to have transmissible levels of virus in 2018 . Of which, an estimated $36 \%$ were undiagnosed, $51 \%$ were diagnosed but untreated and $13 \%$ were treated but had unsuppressed viral load (Figure 3). By subregion, $16 \%$ of people with presumed transmissible levels of virus lived in the West, $1 \%$ in the Centre and $83 \%$ in the East. Excluding Russia (which constituted $60 \%$ of all PLHIV with transmissible levels of virus in the entire Region) the figures become $41 \%, 3 \%$ and $56 \%$, respectively.

\section{FIGURE 1}

The continuum of HIV care as envisaged by the 90-90-90 UNAIDS targets by 2020

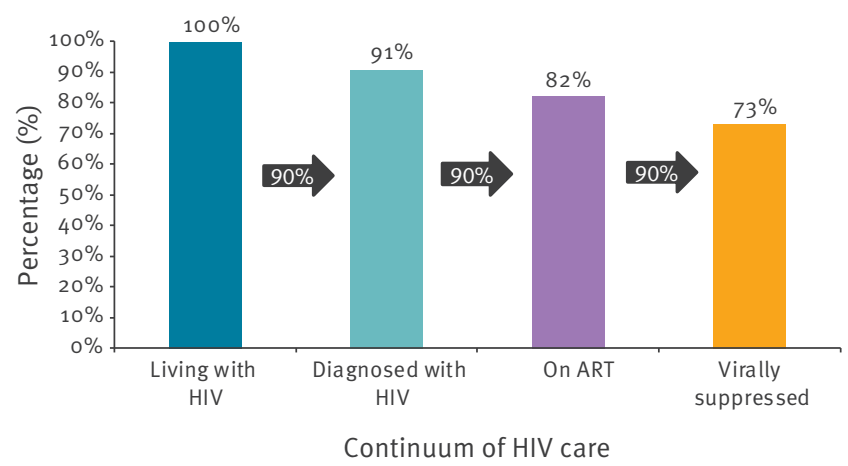

ART: antiretroviral therapy; PLHIV: people living with HIV; UNAIDS: Joint United Nations Programme on HIV/AIDS.

Global 90-90-90 target: each stage of the continuum is presented as a percentage of the previous stage of the continuum, with target of $90 \%-90 \%-90 \%$.

Substantive target: each stage of the continuum is presented as a percentage of the total number of people living with HIV, with target of $90 \%-81 \%-73 \%$

Numbers of PLHIV are rounded to the nearest hundred and reported only where available.

Graph is adapted from [1].

\section{Discussion}

There has been substantial progress towards achieving the global UNAIDS targets across Europe and Central Asia and improvements have been recognised across all three WHO subregions. Despite this, only two-fifths of all PLHIV across the Region are estimated to be virally suppressed in 2018. While the West subregion exceeded the $73 \%$ substantive target, only around a half (Centre) and a quarter (East) of PLHIV are virally suppressed. The substantial progress between 2016 and 2018 is indicative of the improvements that can be made on a Regional scale in a short amount of time; this should provide reassurance and incentive to other global Regions that still have much work in order to meet the 90-90-90 ambition [8].

Each country should assess its progress against 90-90-90 targets and compare outcomes against Regional performance to drive further improvement. Only 34 of 55 countries provided data on all four continuum stages. Improved data availability is crucial to better monitor the effectiveness of their public health response to HIV. Countries that are unable to monitor the continuum of care need support to develop the infrastructure and data flows to enable them to do so. Improvements in ART access are likely to have positively influenced the outcomes. Four countries recommended ART initiation regardless of $\mathrm{CD}_{4}^{+}$cell count ('test and treat') in 2014, 16 in 2016 and 14 in 2018. Treatment 
TABLE A

Progress against the global 90-90-90 targets reported, European and Central Asian countries, $2018(\mathrm{n}=52)$

\begin{tabular}{|c|c|c|c|c|c|c|c|c|c|}
\hline \multirow{3}{*}{$\begin{array}{l}\text { WHO } \\
\text { subregion }\end{array}$} & \multirow{3}{*}{ Country } & \multicolumn{4}{|c|}{ Total numbers } & \multicolumn{3}{|c|}{ Global 90-90-90 Targets } & \multirow{2}{*}{$\begin{array}{c}\text { Substantive } \\
\text { Target }\end{array}$} \\
\hline & & \multirow[t]{2}{*}{ All PLHIV } & \multirow[t]{2}{*}{ Diagnosed } & \multirow[t]{2}{*}{ Treated } & \multirow[t]{2}{*}{$\begin{array}{c}\text { Virally } \\
\text { suppressed }\end{array}$} & $\begin{array}{c}\% \text { of } \\
\text { PLHIV } \\
\text { who are } \\
\text { diagnosed }\end{array}$ & $\begin{array}{c}\text { \% of } \\
\text { diagnosed } \\
\text { PLHIV } \\
\text { who are } \\
\text { receiving } \\
\text { ART }\end{array}$ & $\begin{array}{l}\text { \% receiving } \\
\text { ART who } \\
\text { are virally } \\
\text { suppressed }\end{array}$ & \\
\hline & & & & & & $\begin{array}{l}2020 \\
\text { target: } \\
90 \%\end{array}$ & $\begin{array}{l}2020 \\
\text { target: } \\
90 \%\end{array}$ & $\begin{array}{c}2020 \text { target: } \\
90 \%\end{array}$ & $\begin{array}{c}2020 \text { target: } \\
73 \%\end{array}$ \\
\hline \multirow{24}{*}{$\begin{array}{l}\text { West } \\
(n=23 \\
\text { countries) }\end{array}$} & Andorra & NA & 68 & 68 & NA & NA & 100 & NA & NA \\
\hline & Austria & 7,079 & 6,537 & 6,145 & 5,223 & 92 & 94 & 85 & 74 \\
\hline & Belgium & 18,758 & 15,885 & 13,763 & 12,759 & 85 & 87 & 93 & 68 \\
\hline & Denmark & 6,000 & 5,500 & 5,300 & 5,200 & 92 & 96 & 98 & 87 \\
\hline & Finland & 3,880 & 3,401 & NA & NA & 88 & NA & NA & NA \\
\hline & France & 156,600 & 132,400 & 120,700 & 116,600 & 85 & 91 & 97 & 74 \\
\hline & Germany & 86,100 & 74,800 & 68,800 & 65,500 & 87 & 92 & 95 & 76 \\
\hline & Greece & 16,665 & 13,866 & 9,594 & NA & 83 & 69 & NA & NA \\
\hline & Iceland & NA & NA & NA & NA & NA & NA & NA & NA \\
\hline & Ireland & 7,205 & 6,276 & 5,227 & 4,986 & 87 & 83 & 95 & 69 \\
\hline & Israel & 8,039 & 7,448 & 5,087 & NA & 93 & 68 & NA & NA \\
\hline & Italy & 130,000 & 114,400 & 100,000 & 87,000 & 88 & 87 & 87 & 67 \\
\hline & Liechtenstein & NA & NA & NA & NA & NA & NA & NA & NA \\
\hline & Luxembourg & 1,081 & 919 & 812 & 751 & 85 & 88 & 92 & 69 \\
\hline & Malta & 453 & 340 & 340 & 298 & 75 & 100 & 88 & 66 \\
\hline & Monaco & 47 & 47 & 47 & 47 & 100 & 100 & 100 & 100 \\
\hline & The Netherlands & 22,900 & 20,264 & 18,599 & 17,580 & 88 & 92 & 95 & 77 \\
\hline & Norway & NA & NA & NA & NA & NA & NA & NA & NA \\
\hline & Portugal & 38,959 & 35,709 & 31,000 & 28,007 & 92 & 87 & 90 & 72 \\
\hline & Spain & 146,000 & 120,000 & 116,408 & 103,000 & 82 & 97 & 88 & 71 \\
\hline & Sweden & 8,320 & 7,489 & 7,261 & 6,930 & 90 & 97 & 95 & 83 \\
\hline & Switzerland & 16,600 & 15,000 & 14,400 & 13,900 & 90 & 96 & 97 & 84 \\
\hline & United Kingdom & 101,400 & 91,987 & 88,089 & 85,446 & 91 & 96 & 97 & 84 \\
\hline & West total ${ }^{a}$ & 776,086 & 672,336 & 611,640 & 553,227 & 87 & 91 & 93 & 74 \\
\hline \multirow{16}{*}{$\begin{array}{l}\text { Centre } \\
(n=15 \\
\text { countries) }\end{array}$} & Albania & 1,300 & 891 & 568 & 312 & 69 & 64 & 55 & 24 \\
\hline & Bulgaria & 2,862 & 2,410 & 1,198 & 689 & 84 & 50 & 58 & 24 \\
\hline & Croatia & 1,533 & 1,077 & 919 & 822 & 70 & 85 & 89 & 54 \\
\hline & Cyprus & NA & NA & NA & NA & NA & NA & NA & NA \\
\hline & Czech Republic & 3,230 & 2,533 & 1,800 & 1,660 & 78 & 71 & 92 & 51 \\
\hline & Hungary & NA & NA & NA & NA & NA & NA & NA & NA \\
\hline & Kosovo* & NA & NA & NA & 15 & NA & NA & NA & NA \\
\hline & $\begin{array}{l}\text { The former Yugoslav } \\
\text { Republic of } \\
\text { Macedonia, }\end{array}$ & 383 & 246 & 198 & 191 & 64 & 80 & 96 & 50 \\
\hline & Montenegro & 437 & 201 & 140 & 121 & 46 & 70 & 86 & 28 \\
\hline & Poland & NA & NA & NA & NA & NA & NA & NA & NA \\
\hline & Romania & 17,000 & 15,009 & 11,570 & 8,409 & 88 & 77 & 73 & 49 \\
\hline & Serbia & 2,700 & 2,441 & 1,724 & NA & 90 & 71 & NA & NA \\
\hline & Slovakia & 995 & 756 & 540 & NA & 76 & 71 & NA & NA \\
\hline & Slovenia & 987 & 670 & 533 & 530 & 68 & 80 & 99 & 54 \\
\hline & Turkey & NA & NA & NA & NA & NA & NA & NA & NA \\
\hline & Centre total $^{\mathrm{a}}$ & 31,427 & 26,234 & 19,190 & 12,749 & 83 & 73 & 75 & 46 \\
\hline
\end{tabular}

ART: antiretroviral therapy; NA: Not available; PLHIV: people living with HIV; WHO: World Health Organization.

a Totals reflect sum of values presented. However only countries with data for consecutive stages of the continuum are included in the global 90-90-90 target outcomes and only countries with all four elements are included in substantive target outcome.

* This designation is without prejudice to positions on status, and is in line with UNSC 1244 and the ICJ Opinion on the Kosovo Declaration of Independence. 
Progress against the global 90-90-90 targets reported, European and Central Asian countries, 2018 ( $\mathrm{n}=52)$

\begin{tabular}{|c|c|c|c|c|c|c|c|c|c|}
\hline \multirow{3}{*}{$\begin{array}{l}\text { WHO } \\
\text { subregion }\end{array}$} & \multirow{3}{*}{ Country } & \multicolumn{4}{|c|}{ Total numbers } & \multicolumn{3}{|c|}{ Global 90-90-90 Targets } & \multirow{2}{*}{$\begin{array}{c}\text { Substantive } \\
\text { Target } \\
\\
\text { \% of PLHIV } \\
\text { who are virally } \\
\text { suppressed }\end{array}$} \\
\hline & & \multirow[t]{2}{*}{ All PLHIV } & \multirow[t]{2}{*}{ Diagnosed } & \multirow[t]{2}{*}{ Treated } & \multirow[t]{2}{*}{$\begin{array}{l}\text { Virally } \\
\text { suppressed }\end{array}$} & $\begin{array}{c}\% \text { of } \\
\text { PLHIV } \\
\text { who are } \\
\text { diagnosed }\end{array}$ & $\begin{array}{c}\% \text { of } \\
\text { diagnosed } \\
\text { PLHIV } \\
\text { who are } \\
\text { receiving } \\
\text { ART }\end{array}$ & $\begin{array}{l}\text { \% receiving } \\
\text { ART who } \\
\text { are virally } \\
\text { suppressed }\end{array}$ & \\
\hline & & & & & & $\begin{array}{l}2020 \\
\text { target: } \\
90 \%\end{array}$ & $\begin{array}{c}2020 \\
\text { target: } \\
90 \%\end{array}$ & $\begin{array}{c}2020 \text { target: } \\
90 \%\end{array}$ & $\begin{array}{c}2020 \text { target: } \\
73 \%\end{array}$ \\
\hline \multirow{16}{*}{$\begin{array}{l}\text { East } \\
\text { ( } n=14 \\
\text { countries) }\end{array}$} & Armenia & 3,400 & 2,265 & 1,530 & 1,304 & 67 & 68 & 85 & 38 \\
\hline & Azerbaijan & 8,003 & 5,661 & 4,207 & 1,778 & 71 & 74 & 42 & 22 \\
\hline & Belarus & 26,120 & 19,231 & 11,242 & 7,253 & 74 & 58 & 65 & 28 \\
\hline & Estonia & 7,900 & NA & 4,109 & NA & NA & NA & NA & NA \\
\hline & Georgia & 10,500 & 5,090 & 4,144 & 3,383 & 48 & 81 & 82 & 32 \\
\hline & Kazakhstan & 26,000 & 20,841 & 11,482 & 6,338 & 80 & 55 & 55 & 24 \\
\hline & Kyrgyzstan & 8,500 & 5,805 & 3,237 & 1,995 & 68 & 56 & 62 & 23 \\
\hline & Latvia & NA & NA & NA & NA & NA & NA & NA & NA \\
\hline & Lithuania & 2,761 & 2,601 & 780 & 609 & 94 & 30 & 78 & 22 \\
\hline & Moldova & 15,132 & 11,887 & 5,162 & 3,324 & 79 & 43 & 64 & 22 \\
\hline & Russia & 998,525 & 808,823 & 319,613 & 27,1671 & 81 & 40 & 85 & 27 \\
\hline & Tajikistan & 15,000 & 7516 & 4,942 & $N A$ & 50 & 66 & NA & NA \\
\hline & Ukraine & 244,000 & 136,378 & 98,237 & 57,010 & 56 & 72 & 58 & 23 \\
\hline & Uzbekistan & NA & 21,364 & 20,281 & 17,530 & NA & 95 & 86 & NA \\
\hline & East total $^{\mathrm{a}}$ & $1,365,841$ & $1,047,462$ & 488,966 & 372,195 & 76 & 46 & 78 & 26 \\
\hline & $\begin{array}{l}\text { Total (Tables A and } \\
\text { B) }\end{array}$ & $2,173,354$ & $1,746,032$ & $1,119,796$ & 938,171 & 80 & 64 & 86 & 43 \\
\hline
\end{tabular}

ART: antiretroviral therapy; NA: Not available; PLHIV: people living with HIV; WHO: World Health Organization.

a Totals reflect sum of values presented. However only countries with data for consecutive stages of the continuum are included in the global 90-90-90 target outcomes and only countries with all four elements are included in substantive target outcome.

* This designation is without prejudice to positions on status, and is in line with UNSC 1244 and the ICJ Opinion on the Kosovo Declaration of Independence.

coverage among the diagnosed population was $89 \%$ for countries implementing 'test and treat' in 2014, $93 \%$ in 2016 and $46 \%$ in 2018 . This, together with the significant variation in outcomes across countries and subregions (including those with similar contexts and epidemics) demonstrates the powerful impact of policy implementation. The substantial drop-off between the percentages diagnosed and treated in the East subregion is concerning since it enables preventable deaths, serious illness and onward transmission.

Characterising the population living with transmissible virus provides new insight into the scale and focus of prevention efforts. Almost two-thirds of the 1.2 million people with transmissible virus across the Region are diagnosed. This indicates that the biggest public health impact could be achieved through rapid and sustained scale up of treatment, particularly in the Centre and East subregions. Across the Region, the large undiagnosed population can be addressed by diversifying and augmenting policies offering HIV tests: for indicator conditions, during screenings for other sexually transmitted infections, in community-based settings, as self/home-testing and for partner notification. New European guidance on setting-based approaches for HIV and hepatitis testing can help countries implement more effective testing programmes [9].

It is unclear whether current progress has impacted on HIV transmission. Recent modelling suggests a viral suppression rate of $90 \%$ among all PLHIV must be reached to reduce incidence [10]. This indicates intensive efforts are required before transmission begins to fall. However, the West subregion, which has met the substantive target, has provided a favourable context in which reductions in HIV transmission are apparent among gay and bisexual men in some settings [11-14]. It is likely further declines will be observed when preexposure prophylaxis (PrEP) is fully implemented to those most at need.

The 90-90-90 targets remain a powerful tool to assess progress towards HIV elimination and drive standards in care for PLHIV. However, they cannot provide a 


\section{FIGURE 2}

Continuum of HIV care (substantive target), overall and by WHO subregion, 2018, and comparison between 2018 and $2016^{\mathrm{a}, \mathrm{b}}$

A. Europe and Central Asian region

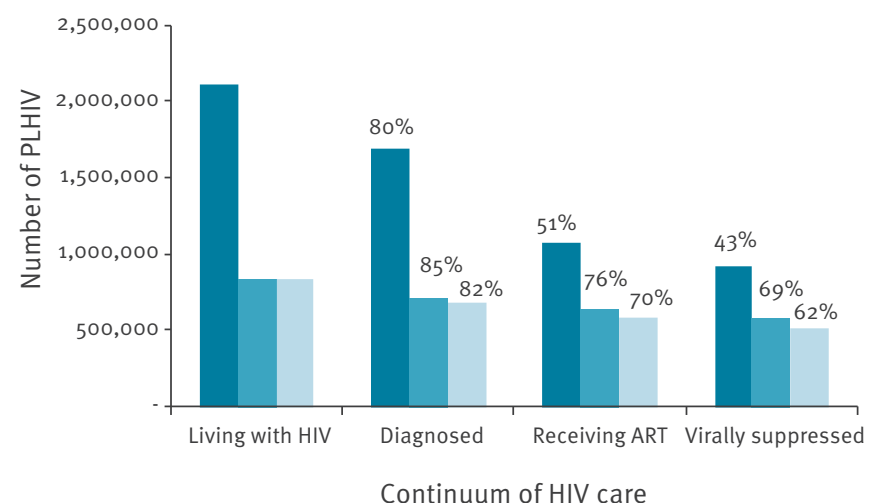

$=2018-2018^{\mathrm{b}}-2016^{\mathrm{b}}$

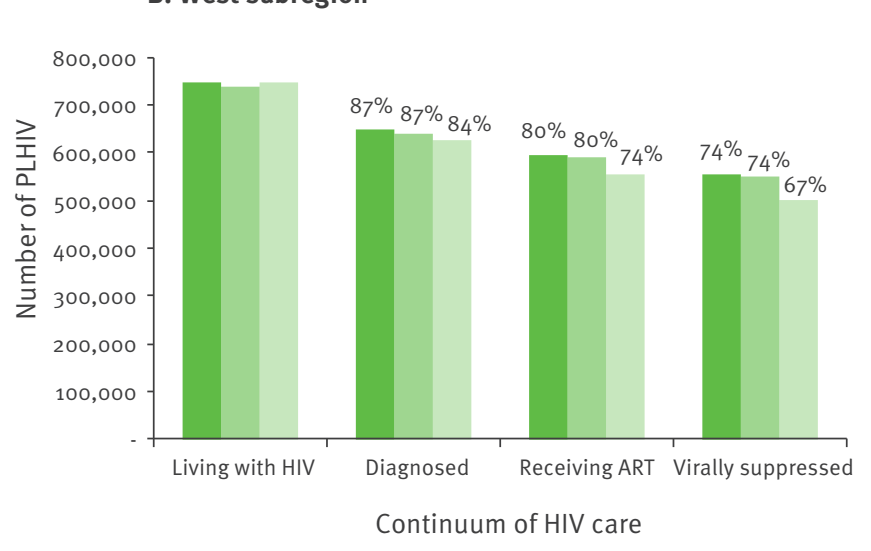

$2018-2018^{\mathrm{b}}-2016^{\mathrm{b}}$
C. Centre subregion

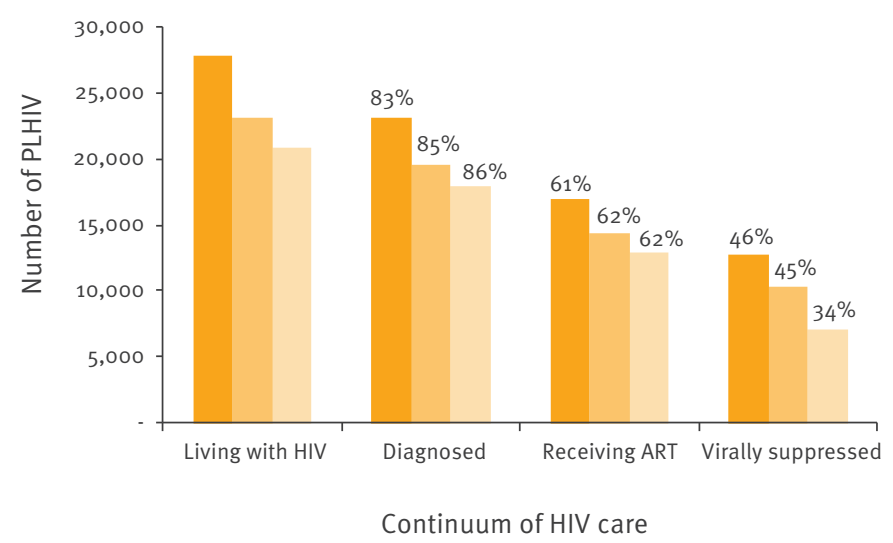

$2018-2018^{b}-2016^{b}$
D. East subregion

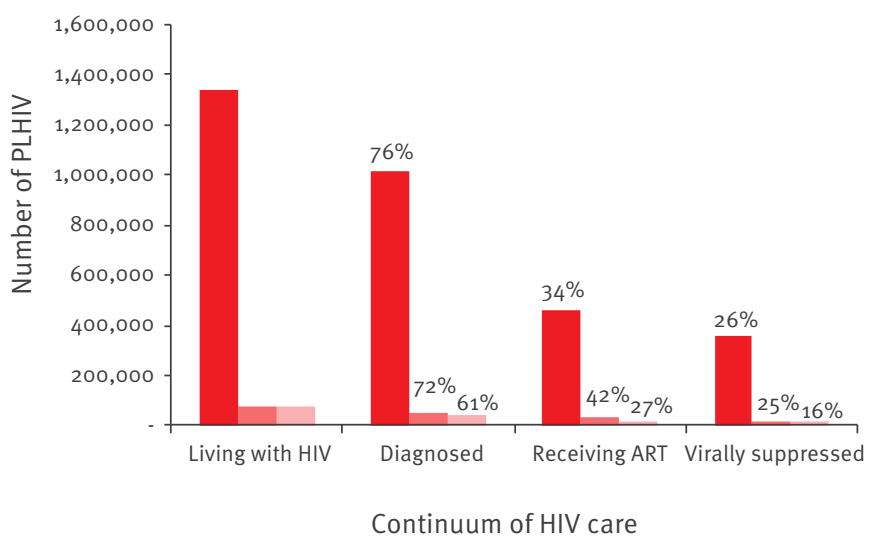

$2018-2018^{\mathrm{b}}-2016^{\mathrm{b}}$

ART: antiretroviral therapy; PLHIV: people living with HIV; WHO: World Health Organization.

a Countries reporting data for both years included: West: Austria, Belgium, Denmark, France, Germany, Italy, Luxembourg, Malta, the Netherlands, Portugal, Spain, Sweden, Switzerland and the United Kingdom; Centre: Albania, Bulgaria, Croatia, Montenegro, Romania; East: Armenia, Azerbaijan, Georgia, Kazakhstan, Kyrgyzstan and Moldova.

${ }^{b}$ Countries providing data for both years.

comprehensive picture of the public health response to HIV. While testing and treatment access are a clear focus, deaths and key interventions such as condom use, PrEP and health promotion are excluded. Results are limited in their representativeness, since only 34 countries provided information for all four stages of the continuum with only 25 providing data for both 2016 and 2018. Furthermore, while continuum methods have been defined, in practice, variations in data availability, sources, timeframes and analysis (such as ability to account for deaths and loss-to-follow-ups) limit direct comparisons. Stage 1 of the continuum is, by necessity, an estimation. It is the part of the continuum that is simultaneously most vulnerable to uncertainty and the most critical since it sets the denominator upon which the 90-90-90 targets are calculated [4]. The estimated number of PLHIV (including number with transmissible virus) underrepresents the true Regional situation since they are presented only where countries report data. 


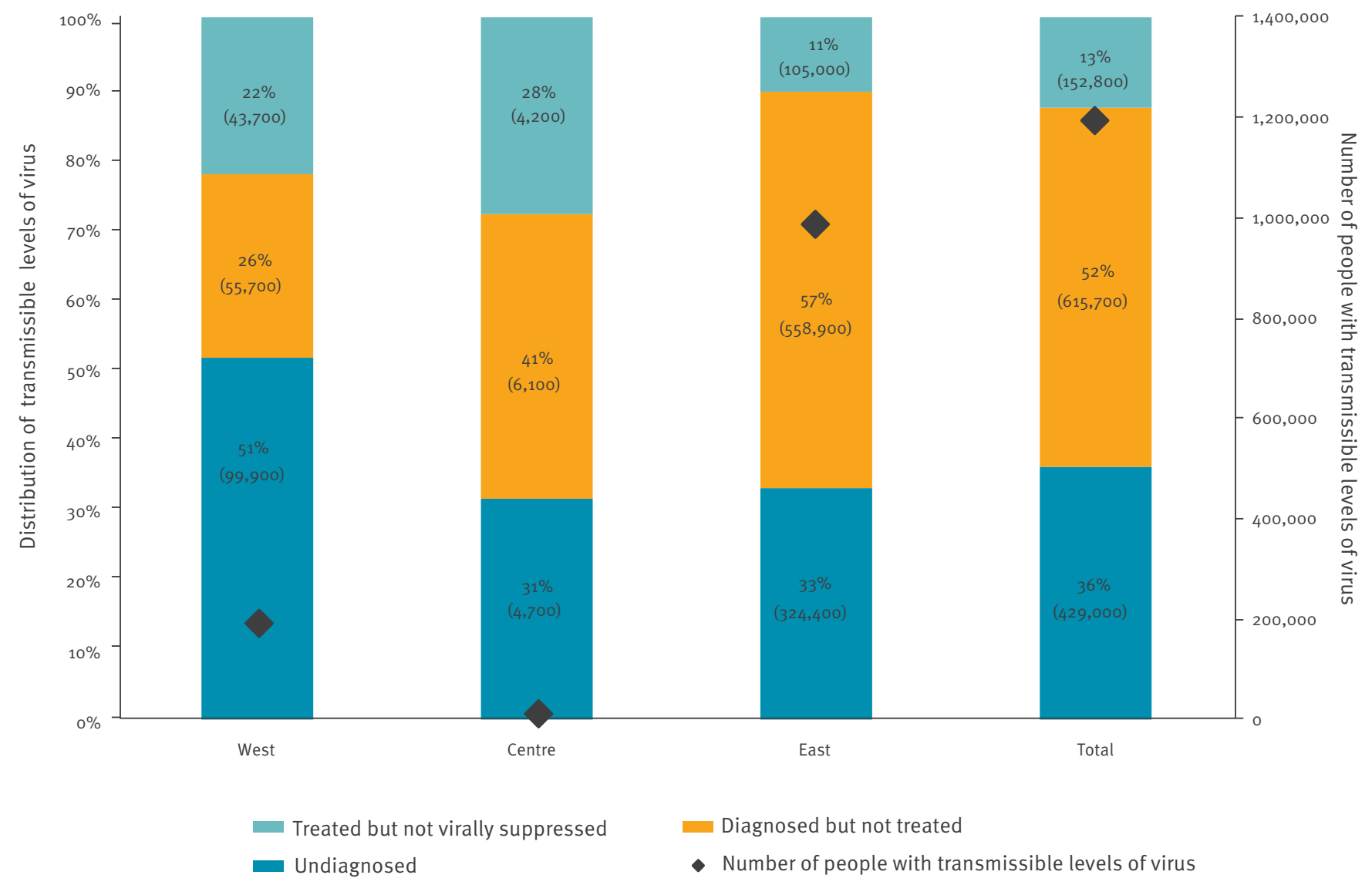

WHO: World Health Organization.

${ }^{a}$ Countries reporting all four stages of the continuum.

A major limitation is that percentage values mask absolute numbers of PLHIV. We recommend that assessment of the 90-90-90 targets must incorporate the number of PLHIV. The analysis of the estimated number of people living with transmissible levels of virus provides further insights. For instance, the high proportion of people with transmissible virus is exacerbated by the large size of the Russian and Ukrainian epidemic. Furthermore, in the United Kingdom, France and Germany, the proportion of people with transmissible HIV is low but masks significant absolute numbers, which impedes efforts to reduce HIV incidence. It is also important to ascertain outcomes for key populations which are known to experience stark inequalities within and between countries [15].

It is crucial not to rest content with meeting the 90-90-90 targets. Each 'last 10 percent' includes people especially marginalised from healthcare services. Beyond the 90-90-90 ambition, intensive efforts in policy and service implementation are vital if the ultimate aim of 'getting to zero' is to become reality.
*This designation is without prejudice to positions on status, and is in line with UNSC 1244 and the ICJ Opinion on the Kosovo Declaration of Independence.

\section{ECDC Dublin Declaration Monitoring Network}

Roland Bani (Albania), Jennifer Fernández Garcia (Andorra), Samvel Grigoryan, Arshak Papoyan, Trdat Grigoryan (Armenia), Irene Kaszoni-Rueckerl, Bernhard Benka (Austria), Esmira Almammadova (Azerbaijan), Inna Karaban, Anna Rusanovich, Svetlana Sergeenko (Belarus), Daniel Reynders, Andre Sasse, Dominique Van Beckhoven (Belgium), Tonka Varleva, Mariya Zamfirova (Bulgaria), Josip Begovac, Tatjana Nemeth-Blazic, Zoran Dominkovic (Croatia), Linos Hadjihannas, Anna Demetriou (Cyprus), Veronika Mičulková, Marek Malý (Czech Republic), Jan Fouchard, Susan Cowan (Denmark), Kristi Rüütel, Tiina Drell (Estonia), Henrikki Brummer-Korvenkontio, Kirsi Liitsola (Finland), JeanChristophe Comboroure. Florence Lot (France), Ketevan Stvilia, Nikoloz Chkhartishvili (Georgia), Gesa Kupfer, Ulrich Marcus, (Germany), Vasilios Raftopoulos, Sotirios Tsiodras, Dimitra Parasekva (Greece), Katalin Szalay, Maria Dudas (Hungary), Guðrún Sigmundsdóttir (Iceland), Caroline Hurley, Derval Igoe, Kate O'Donnell (Ireland), Daniel Chemtob, Yana Levin (Israel), Anna Caraglia, Francesco Maraglino, 
Barbara Suligoi, Lella Cosmaro (Italy), Bayserkin Baurzhan Satzhanovich, Irina Ivanova Petrenko (Kazakhstan), Laura Shehu, Pashk Buzhala (Kosovo*), Ulan Kadyrbekov, Aybek Bekbolotov (Kyrgyzstan), Šarlote Konova, Liva Gramatina (Latvia), Irma Caplinskiene (Lithuania), Andrea Leibold, Marina Jamnicki Abegg (Liechtenstein), Patrick Hoffmann, Carole Devaux, Pierre Weicherding (Luxembourg), Jackie Maistre Melillo, Tanya Melillo (Malta), Iurie Climasevschi, Igor Condrat (Moldova), Dominique De Furst (Monaco), Aleksandra Marjanovic, Alma Cicic (Montenegro), Silke David, Ashna Nakched, Eline Op De Coul, Ard van Sighem (Netherlands), Arild Johan Myrberg, Karl Kristian Bekeng (Norway), Iwona Wawer, Piotr Wysocki (Poland), Isabel Aldir, Teresa Melo, Helena Cortes Martins (Portugal), Mariana Mardarescu, Adrian Streinu-Cercel (Romania), Danijela Simic, Sladjana Baros (Serbia), Jan Mikas, Peter Truska (Slovakia), Irena Klavs (Slovenia), Olivia Castillo, Begoña Rodríguez Ortiz de Salazar, Asuncion Diaz (Spain), Maria Axelsson, Gabriella Hok (Sweden), Stefan Enggist, Axel J. Schmidt (Switzerland), Sayfuddin Karimov, Dilshod Sayburhonov (Tajikistan), Emel Özdemir Şahin, Ayla Aydin (Turkey), Valerie Delpech, Peter Kirwan, Alison Brown, Sara Croxford (United Kingdom), Ihor Kuzin, Violeta Martsynovska, Olga Varetska (Ukraine), Gulufar Normuratova, Nurmat Atabekov (Uzbekistan)

\section{Conflict of interest}

None declared.

\section{Authors' contributions}

$A B, R H, Y A, A P, A A, T N$ and VD were all involved in developing the survey questions related to the continuum of care. Country-specific analyses were undertaken by country members of the Dublin Declaration Monitoring Network. European analyses were undertaken by $A B$ and $R H$ under the supervision of $A P, Y A, V D$ and $T N$. $A B$ and $R H$ undertook the main writing of the manuscript which was reviewed and revised by AP, AA, VD, YA, TN and the Dublin Declaration Monitoring Network. All authors reviewed and approved the final draft.

\section{References}

1. Joint United Nations Programme on HIV/AIDS (UNAIDS). 9090-90: An ambitious target to help end the AIDS epidemic. Geneva: UNAIDS; 2014. Available from: http://www.unaids. org/sites/default/files/media_asset/90-90-90_en.pdf

2. European Centre for Disease Prevention and Control. Dublin Declaration monitoring- 2018 progress questionnaire: https:// ecdc.europa.eu/en/infectious-diseases-public-health/ hiv-infection-and-aids/prevention-and-control/monitoring-o

3. Drew RS, Rice B, Rüütel K, Delpech V, Attawell KA, Hales DK, et al. HIV continuum of care in Europe and Central Asia. HIV Med. 2017;18(7):490-9. https://doi.org/10.1111/hiv.12480 PMID: 28117527

4. Gourlay AJ, Pharris AM, Noori T, Supervie V, Rosinska M, van Sighem A, et al. Towards standardized definitions for monitoring the continuum of HIV care in Europe. AIDS. 2017;31(15):2053-8. https://doi.org/10.1097/ QAD.0000000000001597 PMID: 28906276

5. European Centre for Disease Prevention and Control/WHO Regional Office for Europe. HIV/AIDS surveillance in Europe 2018-2017 data. Copenhagen: WHO Regional Office for Europe; 2018. Available from: https://www.ecdc.europa.eu/en/ publications-data/hivaids-surveillance-europe-2018-2017-data

6. European Centre for Disease Prevention and Control (ECDC). Thematic report: Continuum of HIV care. Monitoring implementation of the Dublin Declaration on Partnership to Fight HIV/AIDS in Europe and Central Asia: 2017 progress report. Stockholm: ECDC; 2017. Available from: https://ecdc. europa.eu/sites/portal/files/documents/Continuum-of-HIVcare-2017.pdf

7. Porter K, Gourlay A, Attawell K, Hales D, Supervie V, Touloumi $\mathrm{G}$, et al. ECDC Dublin Declaration Monitoring Network. Substantial Heterogeneity in Progress Toward Reaching the 90-90-90 HIV Target in the WHO European Region. J Acquir Immune Defic Syndr. 2018;79(1):28-37. https://doi. org/10.1097/QAI.0000000000001761 PMID: 29847474

8. Joint United Nations Programme on HIV/AIDS (UNAIDS). Unaids data 2018. Geneva: UNAIDS; 2018. Available from: http://www.unaids.org/sites/default/files/media_asset/ unaids-data-2018_en.pdf

9. European Centre for Disease Prevention and Control (ECDC) Public health guidance on HBV, HCV and HIV testing in the EU/ EEA:an integrated approach. Stockholm. ECDC. 2018. Available from: https://ecdc.europa.eu/sites/portal/files/documents/ HIV-hepatitis-B-and-C-testing-public-health-guidance.pdf

10. Phillips AN, Cambiano V, Miners A, Lampe FC, Rodger A, Nakagawa F, et al. Potential impact on HIV incidence of higher HIV testing rates and earlier antiretroviral therapy initiation in MSM. AIDS. 2015;29(14):1855-62. https://doi.org/10.1097/ QAD.0000000000000767 PMID: 26372391

11. Brown AE, Mohammed H, Ogaz D, Kirwan PD, Yung M, Nash $S G$, et al. Fall in new HIV diagnoses among men who have sex with men (MSM) at selected London sexual health clinics since early 2015: testing or treatment or pre-exposure prophylaxis (PrEP)? Euro Surveill. 2017;22(25):30553. https://doi. org/10.2807/1560-7917.ES.2017.22.25.30553 PMID: 28662762

12. Institut scientifique de Santé publique (WIV-ISP) (2017). Épidemiologie du sida et de l'infection a vih en Belgique: Situation au 31 decembre 2016 [Epidemiology of AIDS and HIV in Belgium, Situation by 31st December 2016]. French. Available from: https://www.sciensano.be/sites/www.wiv-isp. be/files/rapport_vih_sida_2016_web_1.pdf

13. Visser M, van Aar F, van Oeffelen AAM, van den Broek IVF, Op de Coul ELM, et al. (2017). Sexually transmitted infections including HIV, in the Netherlands in 2016. Available from: https://www.rivm.nl/bibliotheek/rapporten/2017-0003.pdf

14. Swiss Confederation, Federal Office for Public Health. Federal Office for Public Health Bulletin 47/2018. Available from: https://www.bag.admin.ch/dam/bag/fr/dokumente/cc/ Kampagnen/Bulletin/2018/BU_47_18.pdf

15. Brown AE, Attawell K, Hales D, Rice BD, Pharris A, Supervie V, et al. Monitoring the HIV continuum of care in key populations across Europe and Central Asia. HIV Med. 2018;19(7):431-9. https://doi.org/10.1111/hiv.12603 PMID: 29737610

\section{License and copyright}

This is an open-access article distributed under the terms of the Creative Commons Attribution (CC BY 4.0) Licence. You may share and adapt the material, but must give appropriate credit to the source, provide a link to the licence, and indicate if changes were made.

This article is copyright of the authors or their affiliated institutions, 2018. 